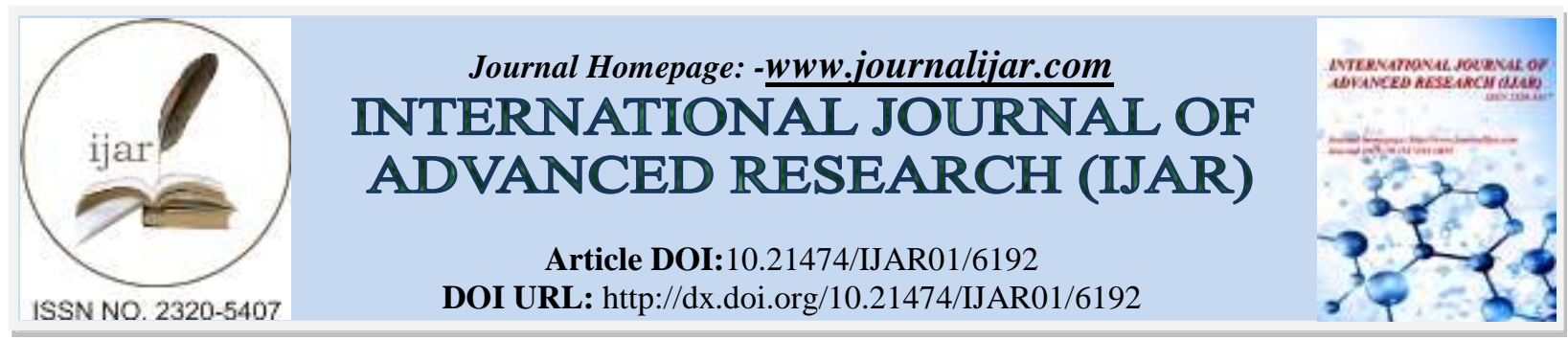

RESEARCH ARTICLE

\title{
THE INFLUENCE OF PRINCIPAL'S PERFORMANCE AND SCHOOL CULTURE ON TEACHER'S PERFORMANCE OF VOCATIONAL HIGH SCHOOL.
}

\author{
Sukris sutiyatno. \\ Lecturer of STMIK Bina Patria, Central-Java, Indonesia.
}

\section{Manuscript Info}

Manuscript History

Received: 02 November 2017

Final Accepted: 04 December 2017

Published: January 2018

Key words:-

Principal's performance, school culture, and teacher's performance.

\begin{abstract}
The purpose of this study was to reveal the influence of principal's performance and school culture on teacher's performance of vocational high school Magelang, Central Java-Indonesia. This study used quantitative approach with survey method. The population of this study was teachers of Vocational High School. The instrument of data collection was by means of questionnaire. The finding of this study revealed that Principal's performance gave a significant positive influence on teacher's performance of vocational high school of Magelang, School Culture gave a significant positive influence on teacher's performance of vocational high school of Magelang, Principal's performance and school culture together gave a significant influence on teacher's performance of vocational high school of Magelang. The result of this study implied that Vocational High School should give more serious attention to the principal's performance and school culture to increase teacher's performance.
\end{abstract}

Copy Right, IJAR, 2018,. All rights reserved.

\section{Introduction:-}

Vocational high school constitutes a formal education which aims to produce a qualified midlle worker. As a formal education, VHS must be responsible for increasing competency and skill of the students so that they are ready to enter labor market either regional or global. VHS must be ready to carry out the development mission to develop the school into national and international standard (Direktorat PMSK, 2008:49).

The purpose of technical and vocational and educational training (TVET) is preparation for work in the labor market. The focus of Technical and Vocational and Educational Training (TVET) is on the job (in contrast, general education focuses on the ability to learn, to understand the environment, and to prepare for the next level). The most important factor in TVET is the relationship of training outputs to employers and the job market (Asian Development Bank, 2009:3). Meanwhile, Gassakov (2006:44) states that TVET always needs to be promoted. Not only does every VET system have to compete for able students, but in many countries, academic, general and higher education all have a higher social and general status than TVET does.

Gill, et al (2000:15) states that the effectiveness of school-based vocational education program appears to depend on their objectives. The most common objectives are, first, to keep less gifted students out of higher education and off the streets, to provide employers with skilled workers and technician. Other objective including providing students with general vocational skills to prepare them for lifelong learning. 
Blase\&Blase (2000:135) states that principals used six strategies to promote professional growth, including: (1) emphasizing the study of teaching and learning; (2) supporting collaboration efforts among educators; (3) developing coaching relationships among educators; (4) encouraging and supporting redesign of programs; (5) applying the principals of adult learning, growth, and development to all phases of staff development; and (6) implementing action research to inform instructional decision making.

The key to the success of school education depends on a good quality school culture, because "school culture influences what people pay attention to (focus), how they identify with the school (commitment), how hard they work (motivation), and the degree to which they achieve their goals (productivity)" (Peterson \& Deal, 2002: 10).

Pashiardis, et al (2011:544) states that the strong interpersonal relationships among the principal and the teachers as well as the principal's approachable personality effectively created a strong culture of cooperation in the school.

Edmond (2011:394) states that the principal must be able: (1) to develop teachers' abilities and skills in strategic planning and development; (2) to enhance the effectiveness of school self-evaluation in school; and (3) to develop a quality culture for school self-evaluation for school improvement. Then, Cosner \& Petterson (2003) states that promoting teachers professional development is the most influential educational leadership behavior.

Asian Development Bank (2009:6) states that TVET (Technical Vocational and Educational Training) contributes to economic growth and competitiveness by enhancing productivity---individual, enterprise, and national.

Based on the statisctics of vocational senior secondary school year (VSSS) Republic of Indonesia year 2016/2017, the number of VSSS both public and private school consists of 13.236 schools, and the number of students is 4.682.913 students (Pusat Data dan Statistik Pendidikan dan Kebudayaan, 2017).

The research aims to reveal the influence of principal's performance and school culture on teacher's performance of Vocational High School in Magelang, Central-Java, Indonesia.

\section{Literature Review:-}

\section{Principal's Performance:-}

Day \& Sammons (2014:7) states that the challenges facing school leaders include; ensuring consistently good teaching and learning, integrating a sound grasp of basic knowledge and skills within a broad and balanced curriculum, managing behavior and attendance, strategically managing resource and the environment, building the school as a professional learning community, and developing partnership beyond the school to encourage parental support for learning and new learning. In addition, the recent thinking regarding school leadership holds principals accountable for the academic performance of learners, even though principals' attention is divided between numerous challenges facing the schools. The presence of these challenges makes leadership an essential component at the school and it becomes imperative for principals to pay more attention to improving conditions that enhance effective teaching and learning (Leithwood\&Riehl, 2003; Steyn, 2008).

Adeyemi (2010:85) states that principals can therefore encourage effective performance of their teachers by identifying their needs and trying to satisfying or meeting them. Meanwhile, Sallis (1994:89) states that a key aspect of the leadership role in education is to empower teachers to give them the maximum opportunity to improve the learning of their students.

Most of school leaders are motivated by the desire to make a difference to their students. They want to lift their students' achievement, increase their confidence, and give them opportunites they would never find elsewhere. Although we should admire their moral purpose, fine words and high ideals are not enough. If leaders don't know how to put their words into action, if they follow the wrong paths and take the wrong turns, then their sense of moral purpose can quickly give way to cynicism, frustration, and fading commitment (Robinson, 2011:1).

It is important for educational leaders to establish a shared strategic overview of the future direction of the organization, clearly focused on the improvement of learning and teaching (Preedy, et al. 2006:1). Then, Towsend (2011:100) states that to think strategically, school leaders must have knowledge about what they have to do, but also knowledge about how to approach the unique set of circumstances and conditions that create the uniqueness of every school. 
Ibukun, et al (2011:248) states that the school leader is required to perform three vital functions: namely, to discern and influence the development of goals and policies; to establish and coordinate educational organizations concerned with planning and implementing appropriate programms; and to procure and manage the resources necessary to support the educational system and its planned programs.

Blase \& Blase (2000:134) states that effective principals demonstrated teaching techniques in classrooms and during conferences; they also modeled positive interactions with students. These forms of modeling were viewed as impressive examples of insructional leadership that primarily yielded positive effects on teacher motivation as well as reflective behavior.

Drysdale \& Gurr (2011:366) states that there are several aspects to successful leadership that are broadly relevant: (1) They had a love for learning, and participated in whatever formal or informal programmes were available; (2) They had a strong career orientation and they accepted personal responsibility for their development to create their own future; (3) Strong personal motivation to create excellent schools and to be excellent leaders drove much of what they did; and (4) The principals fully engaged in professional networks, including regional and state committees, to offer their expertise and to gain from experience both personally and for their schools.

Leadership practices of principals at schools may affect the beliefs, expectation, attitudes, values, norms and practices of teachers, which in turn, have an influence on the culture formation. The extent of relationship of leadership and school culture renders it is impossible to carry out one process without affecting the other (Schein, 2004:10).

\section{School Culture:-}

School cultures are complex web of traditions and rituals built up over time as teachers, students, parents and adminstrators work together and deal with crises and accomplishments. Cultural pattern are highly enduring, have a powerful impact on performance, and shape the ways people think, act, and feel (Deal \& Peterson, 2009:7). Then, Hoy \& Miskel (2008:198) states that a common definition of school climate is the set of internal characteristics that distinguish one school from another and influence the behavior of each school's members.

Peterson (2002:23) suggests that culture is built within a school over time as teachers, school leaders, parents and students work together. It is the school culture that often influences the staff development and profesional growth that takes place within a school. In addition, Hoy \& Miskel (2008:198) states that a common definition of school climate is the set of internal characteristics that distinguish one school from another and influence the behavior of each school's members.

All schools are led by principals, but the difference that exist at schools may be associated mainly with the quality of leadership. The advancement of culture at schools is also dependent on how diligent the principals are in executing leadership function (Steyn, 2008:891).

The school principal is the creator or re-shaper of a school's teacher culture and influences not only the actions of the school staff, but also their motivation and spirit (Deal \& Peterson, 1999). Then, Karakose (2008:570) states that leadership and culture are regarded as related concepts, in the sense that leadership influences the formation of culture. In addition, Steyn (2005:47) states that the ability of principals to deal with effectively with cultural issues emanates from the leadership qualities and knowledge they possess which enable them to integrate well with teachers and students.

A closed relationship exists between school culture and overall school image and effectiveness. Understanding a school's teacher culture is integral of developing a good quality school culture. The key element of school culture relies on the culture. Where there is a high quality, positive, and professional teaching culture, there must be a highquality-school culture (Hsin-Hsiange Lee \& Mao-neng Fred Li, 2015:3).

\section{Teacher's Performance:-}

Hatch (2007) states that performance is doing meaningful work in effective and efficient ways, and performance is meeting the requirements of diverse stakeholder groups and gauge performance by organizations stakeholders. A teacher often encounters performance problems as according to Wendy (2006) there are two types of performance faced by a teacher, teaching performance and managing performance where teaching performance of teachers is 
related to obligations to comply to pedagogical matters whereas in managing performance is more in favor to competence portofolio based on plan, do, check and action philosophy. Teaching performance is focused on learning conducted for students when implementing a learning strategy based on the planned objectives.

Adeyemi (2010:85) states that the teachers' performance could be measured through annual report of his/her activities in terms of teaching, lesson preparation, lesson presentation, mastery of subject matter, competence, teachers' commitment to job and extra-curricula activities.

Day \& Sammons (2014) states that teachers are one of the key elements in any school and effective teaching is one of the key propellers for school improvement. Van Deventer \& Kruger (2003:70) states that teachers in classroom also fulfil leadership functions by motivating and encouraging learners to recognize the importance of learning.

Jones et al.(2006:45) states that experience shows that it is the teacher's own performance, personal and professional skills, expectation and relationship in the classroom that are the key factors in influencing pupil's behaviour, attitudes, and subsequent progress.

Robbins \& Judge (2006) states that teacher's performance is to increase the productivity of teaching and managing performance, in this case the principal is to empower teacher's productivity by (1) defining teacher performance, (2) defining teacher performance appraisal, (3) determining the school goals, (4) creating positive consequences for teachers who achieve performance targets.

\section{Research Method:-}

The research made use of quantitative approach with survey method. The research sites were 3 state of vocational high schools located in Magelang City and the teacher population was 327 people with 77 teachers as the research samples. The sampling process was done by means of proportional random sampling technique. The data was collected by using questionnaire. The data was analysed by using regression. Field (2000:103) states in regression analysis we fit a predictive model to our data and use that model to predict values of the dependent variable (DV) from one or more independent variables (IVs) (p. 103)

\section{Result and Discussions:-}

Regression Analysis:-

Assumption Test:-

Normality:-

Normally distributed data assumption is confirmed by Kolmogorov Smirnov test. The test results obtained Kolfogorov Smirnov coefficient $=0.974$ with probability $(\mathrm{p})=0.299$ on the principal's performance variable; Coefficient Kolmogorov Smirnov $=1.254$ with $\mathrm{p}=0.086$ on the school culture variable; Coefficient Kolmogorov Smirnov $=1.042$ with $\mathrm{p}=0.228$ on teacher's performance variable. Acquisition $\mathrm{p}>0.05$ indicates normal distributed data (Sheskin, 2004: 239). Thus the plan for the use of multiple regression parametric statistics can proceed.

Table 1:- Normality Test Results

\begin{tabular}{|c|l|c|c|}
\hline No & Variable & $\begin{array}{c}\text { Coefficient } \\
\text { k-s }\end{array}$ & Sig \\
\hline 1 & Principal's Performance & 0.974 & 0.299 \\
\hline 2 & School Culture & 1.254 & 0.086 \\
\hline 3 & Teacher's Performance & 1.042 & 0.228 \\
\hline
\end{tabular}

Source: Primary data Processing

\section{Linearity Test:-}

Independent data assumption of linear to dependent variable pattern was confirmed with F test. Result of the test reveals that F-statistic $=33.698$, Sig. $0.000<0.05$ on Principal's performance variable and F-statistic=53.023 Sig. $0.000<0.05$ on school culture variable (table 2). Based on the result, Independent variables are linear to dependent variable. 
Table 2:- Linearity Test Result

\begin{tabular}{|c|l|c|c|}
\hline No & Independent Variable & F $_{\text {test }}$ & Sig \\
\hline 1 & Principal's Performance & 33.698 & .000 \\
\hline 2 & School Culture & 53.023 & .000 \\
\hline
\end{tabular}

Source: Primary data processing

A. Regression test:-

Effect of principal's performance and school culture variables simultaneously on Teacher's performance was evaluated by using multiple-regression statistic. Effect of both independent variables was explained by determination parameters, while effect of each independent variable partially was explained by regression coefficient $(\beta)$.

Table 3:- The Result of Multiple Regression

\begin{tabular}{|l|r|r|r|r|}
\hline \multirow{2}{*}{ Variable } & \multicolumn{2}{|c|}{ Coefficients } & \multirow{2}{*}{$T_{\text {-test }}$} & \multirow{2}{*}{ Sig. } \\
\cline { 2 - 4 } & \multicolumn{2}{|c|}{$\beta$} & & \\
\hline Constant & 0.683 & & 1.738 & .086 \\
\hline X1 - Principal's Performance & 0.354 & 0.357 & 4.068 & .000 \\
\hline X2 - School Culture & 0.491 & 0.501 & 5.714 & .000 \\
\hline Multiple Correlation (R) & 0.722 & & \\
\hline Determination Coefficient $\left(\mathrm{R}^{2}\right)$ & 0.521 & & \\
\hline F & 40.284 & & .000 \\
\hline
\end{tabular}

1) Effect of each independent variable :-

Individual effect of independent variable explains contribution of one variable over dependent variable along with the other variable. They are effect of principal's performance on teacher's performance along with school culture and effect of school culture on teacher's performance along with principal's performance. Based on the table, regression equation explaining individually effect of independent variable is

$$
\mathrm{Y}=0.683+0.354 \mathrm{X} 1+0.491 \mathrm{X} 2
$$

The equation explains

\section{Constant:-}

Constant explains teacher's performance when factors affecting it are omitted. Negative constant indicates that teachers decrease their performance when principal's performance and school culture are not conducted.

\section{Effect of Principal's Performance:-}

Principal's performance in the regression function together with school culture has coefficient of 0.354 explains that principal's performance can influence teacher's performance at 0.354 ceteris paribus. Positive score indicates that increasing principal's performance can increase teacher's performance and decreasing principal's performance has impact on decreasing teacher's performance.

Significance partial effect of non verbal communication was evaluated through $t$ test. The table indicated that $t-$ statistic of principal's performance was 4.068 with $\mathrm{p}<0.05$ indicating significant.

\section{Effect of School Culture:-}

School culture in regression function together with principal's performance has positive regression coefficient of 0.491 explains that increasing school culture can increase teacher's performance and decreasing school culture can decrease teacher's performance ceteris paribus for increase in one unit of school culture can increase teacher's performance of 0.491 unit. Significance of individual effect was evaluated through $t$ test. Table 3 indicates that $t$ statistic for verbal communication/school culture was 5.714 with $\mathrm{p}<0.05$ indicating significant. (the right one is school culture)

2) Simultaneous Effect:-

Determination coefficient $\left(\mathrm{R}^{2}\right)$ indicates contribution of all independent variables simultaneously on dependent variable. The coefficient of 0.521 explains that principal's performance and school culture contribute $52.1 \%$ to 
teacher's performance, while other unstudied variable contribute $47.9 \%$. Significance of determination was evaluated with $\mathrm{F}$ test; result of $\mathrm{F}$ statistic $=40.284$ with $\mathrm{p} \leq 0.05$ indicates significant result.

\section{B. Hypothesis Test:-}

First hypothesis states principal's performance influences significantly on teacher's performance. Multiple regression test indicates regression coefficient $\beta=0.354$ with $\mathrm{p}<0.05$ on principal's performance. $\mathrm{P}<0.05$ indicates significant result. So, it is empirical fact supporting the first hypothesis.

The second hypothesis is that school culture influences significantly on teacher's performance. Multiple regression test indicates regression coefficient $\beta=0.491$ with $\mathrm{p}<0.05$ on school culture. $\mathrm{P}<0.05$ indicates significant result. So, it is empirical fact supporting the second hypothesis.

The third hypothesis states principal's performance and school culture influence simultaneously on teacher's performance. Result of regression test shows determination coefficient of 0.521 with $p<0.05$. Result of $p<0.05$ indicates significant result and empirical facts supporting the third hypothesis.

\section{Discussion:-}

Principal's performance and school culture are revealed to give significant influence on teacher's performance of Vocational High School. Its contribution can be explained statistically by $52.1 \%$, where school culture contributes higher $(\beta=0.491)$ than principal's performance $(\beta=0.354)$.

The findings of this research can be utilized to strengthen the results of previous research, Hsin-Hsiange Lee \& Mao-neng Fred Li (2015: 1) found the school leaders, especially the principal, had a critical impact on the development of the school's teacher culture via their determination and encouragement. Both the school and school's senior teachers played an exemplary and leading role in shaping a high-quality school culture for professional development.

Effective principals also encourage continual professional learning. They emphasize research based strategies to improve teaching and learning and initiate discussion about instructional approaches, both in team and with individual teachers, They pursue these strategies despite the preference of many teachers to be left alone (Leithwood et al., 2004). Meanwhile, Spiro (2015) reported on five key practices of effective principal as published by the Wallace Foundation. Examples of effective principals were shared using practices: shaping a vision of success for all students, creating a climate hospitable to education, cultivating leadership in others, improving instruction, and managing people, data, and processes to foster school improvement.

Principals are powerful presence. Their influence impacts teachers as well as student. Manthy (2006: 26) noted "When teachers believe they can positively effect student achievements, schools may be able to succeed when it had been thought impossible". In addition, Papa (2011:4) states a principal's mission must now include designing and implementing new strategies to help teachers and student recoqnize, understand, and integrate tehnology with teaching and learning in the classroom.

Pashiardis, et al. (2011:548) states that the principal's emphasis on the school vision and his consequent support to the teachers in order to facilitate the implementation of the goal set, promoted the creation of a strong organizational culture by which teachers worked collectively for the good of school.

Principal must be able to balance all of those elements while being aware of what impacts the climate of a school in order to meet demands and maximize outcomes (Leithwood\& Sun, 2012 in Spicer 2016:4). Hoy \& Hoy (2003:2) states that the principal, however, is responsible for developing a school climate that is conducive to providing the very best practice instructional practices.

Educational leaders are regarded as having a direct influence on the way in which schools function and are managed. The principal can be held accountable for the academic performance of the learners and the general advancement of a school (Kruger, 2003:206). They are strategically positioned in the leadership hierarchy of the school to enable them to direct, create and maintain a school culture that enables educators and learners to work effectively (Oluremi, 2008:302). 
Peterson (2002) suggests that culture is built within a school over time as teachers, school leaders, parents and student work together. It is the school culture that often influences the staff development and professional growth that takes place within a school (In Ohlson, 2009:103). However, an essential dimension of school climate that school leaders must embrace is the power of the relationship between and among the adults and students in the school building all of which influence the character of a schools and enhances the overall quality of schoollife (Handford\&Leithwood, 2013). The principal plays a crucial role in the development of a healthy culture (Lindahl, 2011).

Experience shows that it is the teacher's own performance, personal and professional skills, expectation and relationship in the classroom that are the key factors in influencing pupil's behaviour, attitude, and subsequent progress ( Jones et al., 2006:45)

Teachers have a positive perception of their leaders when these leaders encourage learning and instructional improvement, make expectation clear, give the opportunity to express ideas and concerns, and build collegiality (Hill \& And, 1995 in spicer, 2016:25). Sahin (2011: 1921) attests, "Principal can promote a positive culture by acting in certain way that sends signals to teachers and students that they can achieve more". Then, Robinson (2011:104) states that the most powerful way that school leaders can make a difference to the learning of their students is by promoting and participating in the professional learning and development of their teachers.

Teachers' job performance could be described as the duties performed by a teacher at a particular period in school system in achiving organizational goal (Obilade, 1999 in Adeyemi, 2010: 85). Studies of direct effects of principal behavior on teachers and classroom instruction include Sheppard's (1996) synthesis of research demonstrating the relationship between certain principal behaviors and teacher commitment, involvement, and innovation (Blasé \& Blasé, 2000:131).

Robbins \& Judge (2006) states that teacher's performance is to increase the productivity of teaching and managing performance, in this case the principal is to empower teacher's productivity by 1) defining teacher performance, (2) defining teacher performance appraisal, (3) determining the school goals, (4) creating positive consequences for teachers who achieve performance targets.

\section{Conclusions and Suggestions:-}

\section{Conclusions:-}

The result of the regression test shows that the effect of independent variable to dependent variables individually and simultaneously. Based on these findings, it is concluded;

1. Principal's performance gives a significant positive influence on teacher's performance of vocational high school of Magelang $(\beta=0,354, \mathrm{p}=<0,05)$.

2. School Culture gives a significant positive influence on teacher's performance of vocational high school of Magelang $(\beta=0,491, \mathrm{p}<0,05$

3. Principal's performance and school culture together give a significant influence on teacher's performance of vocational high school of Magelang $\left(\mathrm{R}^{2}=0.521, \mathrm{~F}\right.$-test $\left.=40.284, \mathrm{p}<0.05\right)$

\section{Suggestions:-}

Considering the finding of this research that principal's performance and school culture give an influence effect on teacher's performance, the researcher recommends that school principals should pay more attention to improve and empower the teacher's performance to increase the quality of teaching learning process. Vocational High School should also improve and maintain the school culture to improve a qualified atmosphere for the teachers to increase their performance. 


\section{References:-}

1. Adeyemi, T.O. (2010). Principal's leadership styles and teachers'job performance in senior secondary schools in Ondo State, Nigeria. Journal of Education Administration and Policy Studies Vol. 2 (6), pp. 83-91

2. Asian Development Bank. (2009). Good practice in technical and vocatioanal education and training. Manila: Philipine

3. Blase, J \& Blase, J. (2000). Effective instructional leadership. Journal of Educational Administration, 38 (2) pp.130-141.

4. Cosner, S. \& Peterson, K. (2003). Building a learning community. Leadership, 32 (5), 12-15.

5. Day, C \& Sammons, P. (2014). Succesful school leadership. Reading, UK: Education Development Trust.

6. Deal, T.F., \& Peterson, K.D. (1999). Shaping school culture: The heart of leadership. San Fransisco, CA: Jossey-Bass Publisher

7. Deal, T.E., \& Peterson, K.D. (2009). Shaping School Culture. San Fransisco: Jossey-Boss

8. Departemen Pendidikan Nasional. (2005). Peranan kepala sekolah sebagai kunci keberhasilan smk. Jakarta: Direktorat Pembinaan SMK.

9. DepartemenPendidikanNasional. (2008). Peranan smk dalam mendukung pertumbuhan ekonomi daerah. Jakarta: DirektoratPembinaan SMK

10. Drysdale, L \& Gurr, D. (2011). Theory and practice of successful school leadership in Australia. Journal School Leadership and Management, 31, 355-368

11. Edmond, H.F. (2011). Exploring the role of leadership in facilitating teacher learning in Hongkong. Journal School Leadership and Management, 31, 393-410

12. Field, A. (2000). Discovering statistics using SPSS. London: SAGE Publications

13. Gasskov, V.(2006). Vocational education and Training Institutions. Geneva: ILO

14. Gill, Fluitman\& Dar.(2000). Vocational Education \& Training Reform. New York: Oxford University Press

15. Handford,V., \&Leithwood, K. (2013). Why teachers trust school leaders. Journal of Educational Administration, 51 (12), 194-212

16. Hatch, Mary Jo. (2007). Organization theory, modern, symbolic, and postmodern perspectives. New York: Oxford University Press

17. Hill, F. H., and \&And, O. (1995). Establishing a collaborative climate: perception of a first year principal and Faculty

18. Hoy, W.K. \& Miskel, C.G. (2008). Educational administration. New York: McGraw-Hill.

19. Hoy, A.W. \& Hoy, W.K. (2009). Instructional leadership. Boston: Allyn and Bacon. The development of a school's teacher culture and teaching effectiveness: A case study of an award-winning teaching team at an elementary school. IJEPL, Vol 10 (4).

20. Hoy, A.W., \& Hoy, W.K. (2003). Instructional Leadership. Boston: A Pearson Education Company

21. Hsin-Hsiange Lee \& Mao-neng Fred Li. (2015). Principal Leadership and Its links the development of a school's teacher culture and teaching effectiveness: A case study of an award-winning teaching team at an elementary school. International Journal of Education Policy \& Leadership, Vol 10 (4), p. 1

22. Ibukun, W.O., Oyewale, B.K., \& Abe, T.O. (2011). Personality Charateristics and Principal Leadership Effectiveness in Ekiti State. International Journal of Leadership Studies, 6, 247-262

23. Jones, J., Jenkin, M., \& Lord, S. (2006). Developing Effective Teacher Performance. London: Paul Chapman

24. Karakose, T. (2008). The perception of primary teachers on principal cultural leadership behaviours. Educational Sciences: Theory \& Practice, 8(2), 569-579

25. Kruger, A. G. (2003). Instructional leadership: the impact on the culture of teaching and learning in two effective secondary schools. South African Journal of Education, 23(3), 206-211

26. Leithwood et al. (2004). Review of Research: How leadership influences students learning. Wahlstrom: University of Minnesota and University of Toronto

27. Leithwood, J.P. \&Riehl, C. (2003). What we know about successful school leadership. American Educational Research Association, Spring January.

28. Leithwood, K. \& Sun, J. (2012). The nature of effects of transformational school leadership: A meta-analytic review of unpublished research. Educational Administration Quarterly [serial online], 48(3), 387-423.

29. Lindahl, R. (2011). The crucial role of assessing the school's climate in planning school improvement. Educational Planning, 20(1), 16-30.

30. Manthy, G. (2006). Collective efficiacy: Explaining school achievement. Leadership, 35(3), 23-36.

31. Obilade, S.O. (1999). Leadership qualities and styles as they relate to instructional productivity. The Manager Ibadan: Department of Educational Management, University of Ibadan, pp. 25-32 
32. Ohlson,M. (2009). Examining instructional leadership: A study of school culture and teacher quality characteristics influencing student outcomes. Florida Journal of Educational Administration \& Policy, 2(1), 102-113.

33. Oluremi, O.F. (2008). Principals' instructional ledership in successful Hispanic majority high schools. A Journal of International Social Research, 1(3), 301-311, Spring.

34. Papa, R. (2011). Technology Leadership for School Improvement. London: SAGE Publication

35. Pashiardis, P., Savvides, V., Lytra, E., et al. (2011). Succesful school leadership in rural contexs: The case of cyprus. Journal of Educational Management Administration \& Leadership, 39 (5) pp.536-553.

36. Peterson. (2002). Positive or negative. Journal of Staff Development, 2002, 23 (3).

37. Peterson, K., \& Deal, T. (2002). Shaping school culture. San Francisco: Jossey-Bass

38. Preedy, M., Glatter, R., \& Wise, C. (2006). Strategic Leadership and Educational Improvement. London: Paul Chapman

39. Pusat Data danStatistikPendidikandanKebudayaan. (2017). Statistik sekolah menengah kejuruan (smk). Jakarta: Setjen, Kemdibud

40. Rapp, S. (2011). The director of education as a leader of pedagogical issues: a research of leadership in municipal educational sector activities. Journal of School Leadership and Management, 31, pp.471-490.

41. Robinson, V. (2011). Student-centered leadership. United State of America: Jossey-Bass.

42. Robbins, S,P., \& T.A. Judge. (2006). Organizational behavior. Bandung: Pearson-Prentice Hall \&Mandarmaju, pp. 231-232

43. Sahin, S. (2011). The relationship between instructional leadership and ethical climate. Educational Sciences. Theory and Practice, 11(4), 1920-1927

44. Sallis, E. (1994). Total Quality Managemen in Education. London: Kagan Page Limited

45. Schien, E.H. (2004). Organisational culture and leadership. San Francisco: Jossey-Bass

46. Sheppard, B. (1996). Exploring the transformational nature of instructional leadership. The Alberta Journal of Educational Research, 42(4), pp. 325-44

47. Sheskin, D., J. (2004). Parametric and nonparametric statistical procedures. Chapman \&HalVCRC, US.

48. Spicer, F. V. (2016). School culture, school climate, and the role of the principal. Educational policies Studies Dissertations. Georgia State University

49. Spiro, J.J. (2015). Effective principal in action. Principal's Research Review, 10(1), 1-6.

50. Steyn, G.M. (2005). The influence of educational leadership in inviting schools in the United States of America. South African Journal of Higher Education, 25(4), 889-905.

51. Steyn, G.M. (2008). The influence of school leadership preparation programmes: Identification of possible focus areas. South African Journal of Higher Education, 22(4), 889-905.

52. Towsend, T. (2011). School leadership in the twenty-first century: different approaches to common problems?. Journal of School Leadership and Management, 02, 93-103

53. Van Deventer, I \& Kruger, A.G. (2003). An educator's guide to school management skills. Pretoria: Van Schaik

54. Wendy, F.T. (2006). The influences of teacher knowledge and authentic formative assessment on student learning in tecahnology education. International Journal of Technology and Design Education, 16 (1), 53-77. 